\title{
THE UPPER INDUS BASIN.
}

Sir,-Under this heading in the August Journal of the Geological Society, Mr. Drew gives us an excellent collection of facts admirably illustrated with drawings. In theorizing on these facts Mr. Drew supports throughout the view which I had the honour to advance in the Geological Magazine (Vol. IV. 1867, p. 205), under the head of "Valley Terraces," namely, that the parallel terraces are the remains of river alluviums, and that they are not, as is generally held, shores of ancient lakes, or due to marine action, as is also argued. But beyond this, Mr. Drew's facts cut entirely against his own theories. That is, his facts prove that rain and rivers have made, and are still making, his side "fans," main river alluviums and terraces, and that these are not (according to his theory) due to the glacial epoch (page 470), or to any former "different state of climate" (page 457). His facts also demonstrate that these inland patches of river alluviums (which are not to be confused with those open to the sea) are due to what Mr. Mackintosh has called "Colonel Greenwood's hard gorge and soft valley theory." Every one of Mr. Drew's flat alluviums is immediately above a hard gorge. And this immediate alternation of gorge and flat alluvium is found not only in the Indus valley, but throughout the wide wide world, wherever a river crosses strata of different hardness. Directly as the strata are hard is the narrowness of the gorge which the river cuts. This gorge the river has difficulty to deepen, and atmospheric disintegration and the erosion of rain have difficulty to widen. But throughout the soft strata above the hard gorge the river cuts its bed flat at the level of the gorge, and the atmosphere and the rain easily make and widen a tlat valley. The water of every rain flood is then checked at the narrow gorge, overflows the flat valley, and deposits an annually increasing alluvium on it. But as the alluvium rises by deposit, the bed of the gorge (and consequently of the river above) sinks from erosion, and the time comes when the river can no longer overflow. The confined flooded river then tears down the soft alluvial banks of its own building, and eats them away to the hill-sides, where they remain as parallel terraces. A new flat and a new alluvium is then begun at the new level of the gorge. This process has been repeated for what man may call an eternity of time. It is still going on with unabated vigour, and will continue to go on as long (as Mr. Drew says) " as there are mountains behind to waste."

This is the simple "open Sesame" of Mr. Drew's puzzle (p. 469), "to account for rivers and streams being at one time denuders, at another accumulators, and at a third time denuders again--in other words, to discover why these streams shall at one time lower their beds, cutting down through the rock, at another raise them by depositing alluvium and rising upon it, and at last again lower their beds by cutting down through that alluvium."

\footnotetext{
Brook wood Park, Alregford,

Grongh Grehnwood, Colonel.
} 